\title{
Geographic Distribution and Molecular Variation of Isolates of Three Whitefly-Borne Closteroviruses of Cucurbits: Lettuce Infectious Yellows Virus, Cucurbit Yellow Stunting Disorder Virus, and Beet Pseudo-Yellows Virus
}

\author{
Luis Rubio, Joyce Soong, John Kao, and Bryce W. Falk
}

First, second, and fourth authors: Department of Plant Pathology, 1 Shields Avenue, University of California, Davis 95616; and third author: Seminis Vegetable Seeds, 37437 State Highway 16, Woodland, CA 95695.

Accepted for publication 19 May 1999.

\begin{abstract}
Rubio, L., Soong, J., Kao, J., and Falk, B. W. 1999. Geographic distribution and molecular variation of isolates of three whitefly-borne closteroviruses of cucurbits: Lettuce infectious yellows virus, cucurbit yellow stunting disorder virus, and beet pseudo-yellows virus. Phytopathology 89:707-711.

The geographic incidence and molecular variation of three whiteflyborne closteroviruses (lettuce infectious yellows virus [LIYV], cucurbit yellow stunting disorder virus [CYSDV], and beet pseudo-yellows virus [BPYV]) were studied in cucurbits collected from several distinct geographic locations. Of 498 samples analyzed, none were found to be infected by LIYV. Sixty-nine samples collected in the Middle East and Mediterranean Europe were found infected by CYSDV, and twelve samples
\end{abstract}

ABSTRACT from Crete and Italy were infected by BPYV. Reverse-transcription polymerase chain reaction of a portion of the heat shock protein 70 homolog coding region, followed by single-strand conformation polymorphism and nucleotide sequence analysis, was used to estimate the intra- and interisolate molecular variability. These analyses showed that each BPYV and CYSDV isolate was composed of a population of sequence variants with a nucleotide identity greater than $98 \%$. CYSDV isolates could be divided into two divergent groups. Group I was only composed of isolates from Spain, Jordan, and Turkey, and group II isolates were predominantly found in Saudi Arabia. Nucleotide identity between isolates of the same group was greater than $99 \%$, whereas identity between both groups was less than 92\%. All BPYV isolates showed a nucleotide identity greater than $98 \%$.
A number of whitefly-transmitted viruses that induce yellowing symptoms in their plant hosts have been described recently (11, 28). Most of these viruses including lettuce infectious yellows virus (LIYV) and cucurbit yellow stunting disorder virus (CYSDV) have bipartite single-stranded RNA genomes and are members of the recently recognized genus Crinivirus of the family Closteroviridae (18). The whitefly-transmitted beet pseudo-yellows virus (BPYV) is also a member of the family Closteroviridae, but is currently placed in the genus Closterovirus (18). Like LIYV and CYSDV, BPYV induces yellowing symptoms on infected plants (9). LIYV, CYSDV, and BPYV are transmitted in a noncirculative, nonpropagative manner (semipersistent), but have different whitefly vector specificities. LIYV is transmitted by Bemisia tabaci (Gennadius), CYSDV by B. tabaci and B. argentifolii (Bellows and Perring), and BPYV by Trialeurodes vaporariorum (Westwood) $(4,9,10)$. These three viruses have overlapping plant host ranges and can cause nearly indistinguishable symptoms in their common plant hosts including many species of economic importance such as cucurbits $(3-5,9,10)$.

Recently, the complete nucleotide sequence of the LIYV genomic RNAs was determined (16). Currently, only partial and complete sequences of the heat shock protein 70 (HSP70) homolog genes of CYSDV and BPYV have been determined $(4,6,27)$. This has allowed the design of specific probes and primers for accurate identification of these viruses by using molecular hybridization and reversetranscription polymerase chain reaction (RT-PCR), respectively $(4,15,27)$.

Corresponding author: B. W. Falk; E-mail address: bwfalk@ucdavis.edu

Publication no. P-1999-0629-02R

(C) 1999 The American Phytopathological Society
Accurate identification of specific viruses and determination of their genetic variation are the first steps in designing effective disease control strategies. To date, only limited information is available on the incidences of LIYV, CYSDV, and BPYV, and studies have been mostly confined to limited geographic locations $(3,5,9$, $10)$. LIYV has previously only been reported from limited regions of the United States (28). CYSDV has been reported from regions of Europe and the Middle East, while BPYV is more widespread and overlaps with both LIYV and CYSDV. Similarly, information on the biological and molecular variation of these viruses is lacking. We collected more than 400 cucurbit samples from California (United States), the Middle East (Jordan, Saudi Arabia, and Turkey), and Europe (Spain, Crete, and Italy), and we analyzed these samples for the presence of LIYV, CYSDV, and BPYV. We also estimated the molecular variation of specific regions of the BPYV and CYSDV HSP70 homolog gene by single-strand conformational polymorphism (SSCP) and nucleotide sequence analysis.

\section{MATERIALS AND METHODS}

Biological materials. The LIYV and BPYV isolates were maintained as previously described (27). The CYSDV isolate was used as before (27). Field and greenhouse cucurbit (squash, Cucurbita pepo L.; cucumber, Cucumis sativus L.; watermelon, Citrullus lanatus (Thunb.) Matsum. \& Nakai; and melon, Cucumis melo L.) samples were collected from cucurbit-growing regions of several countries of the Mediterranean basin, the Middle East, and California (Table 1). Samples from Spain, Jordan, and Saudi Arabia were collected from commercial greenhouses and fields; samples from Italy, Crete, and Turkey were collected only from commercial greenhouses; and samples from California were collected only from commercial fields. All samples were collected because they showed at least some typical yellowing symptoms or plants 
were infested with whiteflies. Leaf samples were either frozen at $-70^{\circ} \mathrm{C}$ or air-dried and stored at room temperature until used for analysis.

RNA extraction and hybridization analyses. Total RNAs were extracted from healthy and virus-infected control plant samples as well as field samples using methods described previously (12, 27). Samples for dot-blot hybridization analysis were prepared and applied to membranes as described (27). Digoxigenin-UTP-labeled transcripts specific for LIYV, CYSDV, and BPYV were generated and used in dot-blot hybridization assays as described previously (27).

RT and PCR amplification. Specific oligonucleotide primers for BPYV were designed based on the nucleotide sequence for the HSP70 homolog coding region (27). Primer BH1 (5'-AACTCACCTTACATCCCCACTTGT-3') corresponds to nucleotides 1,311 to 1,335, and primer BH2 (5'-AATGGCTGCTGCAGACGGTTCAAT- $3^{\prime}$ ) is complementary to nucleotides 1,737 to 1,713 . Numbering is based on that for the LIYV HSP70 homolog coding region (16). Primers 410L (5'-AGAGACGGTAAGTAT-3') and 410U (5'TTGGGCATGTGACAT-3') (4) were used to amplify regions of the CYSDV HSP70 homolog coding region.

First-strand cDNA was synthesized using total BPYV and CYSDV RNA as templates. Approximately $300 \mathrm{ng}$ of total RNA was denatured by heating at $95^{\circ} \mathrm{C}$ for $5 \mathrm{~min}$, followed by chilling in ice. The denatured RNAs were reverse-transcribed by incubation at $37^{\circ} \mathrm{C}$ for $1 \mathrm{~h}$ in a $20-\mu \mathrm{l}$ reaction mixture containing first-strand buffer (25 mM Tris-HCl, pH 8.3; $75 \mathrm{mM} \mathrm{KCl}$; and $3 \mathrm{mM} \mathrm{MgCl}_{2}$ ); $1 \mathrm{mM}$ dithiothreitol; $1 \mathrm{mM}$ each of dCTP, dATP, dGTP, and dTTP; 5 units of RNasin (Promega Corp., Madison, WI); 100 units of Moloney murine leukemia virus reverse transcriptase (BRL, Gaithersburg, MD); and $100 \mathrm{ng}$ of the reverse primer (410U for CYSDV and $\mathrm{BH} 2$ for BPYV). An aliquot $(1 / 10)$ of this preparation was PCR-amplified in a $20-\mu l$ reaction mixture containing PCR buffer (50 mM KCl; $10 \mathrm{mM}$ Tris-HCl, $\mathrm{pH} 9.0$; and 1.0\% Triton $\mathrm{X}-100$ ), $1.5 \mathrm{mM} \mathrm{MgCl} 2,1 \mathrm{mM}$ each of the four dNTPs, 2.5 units of Taq DNA polymerase (Promega Corp.), and $50 \mathrm{ng}$ of each primer (BH1 and BH2 for BPYV and 410U and 410L for CYSDV). After an initial denaturation step at $94^{\circ} \mathrm{C}$ for $4 \mathrm{~min}, \mathrm{PCR}$ was performed for 25 cycles, each at $94^{\circ} \mathrm{C}$ for $30 \mathrm{~s}, 60^{\circ} \mathrm{C}$ for BPYV or $40^{\circ} \mathrm{C}$ for CYSDV for $30 \mathrm{~s}$, and $72^{\circ} \mathrm{C}$ for $2 \mathrm{~min}$, followed by an extension step at $72^{\circ} \mathrm{C}$ for $5 \mathrm{~min}$. RT-PCR products were separated by electrophoresis in $5 \%$ polyacrylamide gels at $100 \mathrm{~V}$ and detected by ethidium bromide staining as previously described (27).

SSCP analysis. RT-PCR products were used for SSCP analysis. One microliter of the RT-PCR product was mixed with $9 \mu \mathrm{l}$ of denaturing solution (95\% formamide; $20 \mathrm{mM}$ EDTA, $\mathrm{pH} 8 ; 0.05 \%$ bromophenol blue; and $0.05 \%$ xylene-cyanol) and was denatured by heating at $95^{\circ} \mathrm{C}$ for $5 \mathrm{~min}$. Denatured DNA was electrophoresed at $4^{\circ} \mathrm{C}$ in a nondenaturing $8 \%$ polyacrylamide minigel using a constant voltage of $200 \mathrm{~V}$ for $4.5 \mathrm{~h}$ for CYSDV and $280 \mathrm{~V}$ for $1.75 \mathrm{~h}$ for BPYV (25). The gels were stained with silver nitrate (1).

TABLE 1. Geographic distribution of whitefly-borne closteroviruses

\begin{tabular}{lcccc}
\hline Country $^{\mathrm{a}}$ & Samples analyzed $^{\mathrm{b}}$ & LIYV $^{\mathrm{c}}$ & CYSDV $^{\mathrm{c}}$ & BPYV $^{\mathrm{c}}$ \\
\hline Spain & 78 & 0 & 49 & 0 \\
Jordan & 31 & 0 & 9 & 0 \\
Saudi Arabia & 72 & 0 & 5 & 0 \\
Turkey & 6 & 0 & 6 & 0 \\
Crete & 4 & 0 & 0 & 3 \\
Italy & 10 & 0 & 0 & 9 \\
United States & 297 & 0 & 0 & 0 \\
\hline
\end{tabular}

a Leaf samples were collected from commercial cucurbits in the country indicated.

b Samples were analyzed using dot-blot hybridization using specific probes for lettuce infectious yellows virus (LIYV), cucurbit yellow stunting disorder virus (CYSDV), and beet pseudo-yellows virus (BPYV) (27).

c Indicates the number of samples of those collected that were positive for the virus indicated.
Sequence analysis. RT-PCR products were cloned by mixing approximately $100 \mathrm{ng}$ of cDNA with $50 \mathrm{ng}$ of pGEM-T plasmid (Promega Corp.), followed by ligation and transformation into Escherichia coli $\mathrm{DH} 5 \alpha$. Colonies containing recombinant plasmids were identified using blue-white selection (26). Selection of clones with appropriate inserts was done by direct PCR from colonies using the same primers as used for RT-PCR, followed by gel electrophoresis (26). Sequences of the cDNAs were determined in both directions by means of an ABI PRISM DNA sequencer 377 (Perkin-Elmer, Foster City, CA). Translation to amino acid sequence, multiple alignments, and comparisons of the nucleotide and amino acid sequences were done using the programs Translator, PileUp, and Distances from the Wisconsin GCG software package (7).

\section{RESULTS}

Detection and geographic distribution of BPYV and CYSDV. We analyzed 201 cucurbit plant samples from the Middle East and Europe and 297 samples from California using dot-blot hybridization with probes specific for LIYV, CYSDV, and BPYV as previously described (27). No LIYV was detected in any of the samples. CYSDV and BPYV were detected in 69 and 12 samples, respectively, but only from samples from the Middle East and Europe (Table 1). CYSDV was detected only from cucurbit samples collected in Spain, Turkey, Jordan, and Saudi Arabia. BPYV was found only in cucurbits from Crete and Italy (Table 1).

Detection of CYSDV and BPYV in plant samples was also done by using RT-PCR. Products were obtained by RT-PCR only from samples that also were positive by dot-blot hybridization for the corresponding virus. RT-PCR for CYSDV yielded a single DNA of 465 base pairs (bp), whereas RT-PCR for BPYV gave a single 450-bp DNA. No RT-PCR products were detected from healthy plants or from plants infected by other viruses. The resulting RTPCR products were further used to study the molecular variability of CYSDV and BPYV.

Differentiation of CYSDV and BPYV isolates. Each CYSDV or BPYV sample from an individual plant was considered as a separate isolate. We used SSCP analysis directly on the RT-PCR products in order to rapidly and accurately differentiate CYSDV or BPYV isolates with different nucleotide sequences. As CYSDV and BPYV were not detected in any samples from California, we included in our analysis only the reference BPYV isolate from California used previously (27). Three distinct SSCP patterns were distinguished after analyzing $18 \mathrm{CYSDV}$ isolates (Fig. 1). Pattern 1 was found only for isolates from Spain and Jordan, pattern 2 only for isolates from Turkey, and pattern 3 only for isolates from Saudi Arabia and for one isolate each from Spain and Jordan (Table 2). For BPYV, only two different patterns were identified from the eight isolates (Fig. 1). Pattern A was found for two isolates from Crete, while pattern B isolates were from Crete, Italy, and the refer-

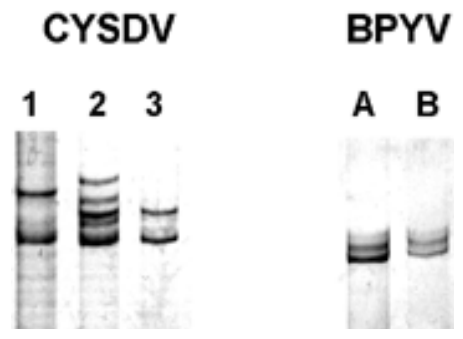

Fig. 1. Different patterns obtained after single-strand conformation polymorphism analysis of reverse-transcription polymerase chain reaction products for 19 cucurbit yellow stunting disorder virus (CYSDV) isolates and 8 beet pseudo-yellows virus (BPYV) isolates. Three patterns $(1,2$, and 3$)$ are shown for CYSDV and two patterns (A and B) for BPYV. Electrophoresis under nondenaturing conditions was performed in $8 \%$ acrylamide gels at $4{ }^{\circ} \mathrm{C}$ at $200 \mathrm{~V}$ for $4.5 \mathrm{~h}$ for CYSDV and at $280 \mathrm{~V}$ for $1.75 \mathrm{~h}$ for BPYV. 
ence isolate from California (Table 2). The difference between these two patterns was very slight but consistent in all of our analyses.

Estimation of the population composition of individual CYSDV and BPYV isolates. All SSCP patterns, except one, showed only two intense bands, suggesting that each RT-PCR product was most likely composed of a single predominant sequence. Only CYSDV pattern 2 showed more than two intense bands. However, SSCP analysis of PCR products from individual clones of this isolate also showed the identical pattern (data not shown). Therefore, this complex pattern might be due to the presence of two or more stable conformations in one or both single DNA strands (13). Sequence variants representing less than $5 \%$ of the total population usually cannot be detected by SSCP analysis of direct RT-PCR products (24). Therefore, in order to estimate more accurately the population composition of these isolates, the RT-PCR products generated from selected isolates were cloned and further analyzed. Ten clones per isolate were selected and amplified by PCR using the original RT-PCR primers. The SSCP patterns of the resulting PCR products were compared with those for the corresponding original RTPCR products. For all isolates, at least 8 of the 10 resulting clones examined showed the same SSCP pattern as did the original RTPCR product, suggesting that all isolates are composed of a predominant sequence.

Estimation of the genetic distance between isolates and between sequence variants of individual isolates. The nucleotide sequences of the cloned RT-PCR products were determined in order to assess the genetic distance within and between virus isolates for the HSP70 coding region. Sequence comparisons between clones with different and indistinguishable SSCP patterns also allowed us to assess the accuracy of SSCP as a means to identify nucleotide sequence variants. The maximum number of nucleotide substitutions for clones with the same pattern was two for CYSDV and three for BPYV (Tables 3 and 4). For all BPYV and CYSDV isolates, clones with different SSCP patterns but belonging to the same virus isolate (from the same RT-PCR product) showed a very high nucleotide sequence identity ( $>98 \%$ ) (data not shown), suggesting that each isolate was composed of highly similar sequence variants. For estimation of the nucleotide sequence distance between isolates, only one of the clones showing the majority SSCP pattern per each isolate was used. Clones of CYSDV isolates showing SSCP patterns 1 and 3 were very similar (identity >99\%) (Table 3). Isolates with patterns 1 and 3 showed a greater divergence with respect to isolates with pattern 2 (identity between 90.8 to $91.2 \%$ ) (Table 3). Therefore, the CYSDV isolates could be divided into two diverging groups (group I for isolates with patterns 1 and 3 and group II for isolates with pattern 2). Despite the distant geographic origin of the different isolates within each group, their sequences were very conserved (Table 3 ). When the deduced amino acid sequences were compared, the differences between all CYSDV isolates were fewer than that seen for nucleotide

TABLE 2. Number of single-strand conformation polymorphism (SSCP) patterns $\mathrm{s}^{\mathrm{a}}$ and country of origin for respective virus samples

\begin{tabular}{lcccccc}
\hline & \multicolumn{3}{c}{ CYSDV $^{\mathrm{c}}$} & & \multicolumn{2}{c}{ BPYV $^{\mathrm{d}}$} \\
\cline { 2 - 4 } \cline { 5 - 6 } Country & Pattern 1 & Pattern 2 & Pattern 3 & & Pattern A & Pattern B \\
\hline Spain & 7 & 1 & 0 & & \\
Jordan & 3 & 1 & 0 & & \\
Saudi Arabia & 0 & 4 & 0 & & \\
Turkey & 0 & 0 & 2 & & 0 & 1 \\
United States & & & & & 3 & 0 \\
Crete & & & & 1 & 3 \\
Italy & & & &
\end{tabular}

a SSCP patterns correspond to those shown in Figure 1.

${ }^{\mathrm{b}}$ Indicates country of origin for virus isolates showing the SSCP pattern indicated.

${ }^{\mathrm{c}}$ Cucurbit yellow stunting disorder virus.

d Beet pseudo-yellows virus.

${ }^{\mathrm{e}}$ Corresponds to the reference isolate from California (27). sequences, indicating that most nucleotide changes were synonymous (less than $20 \%$ of nucleotide changes resulted in amino acid changes) (Table 3). Similarly, all BPYV clones showed a high nucleotide sequence identity $(>98.5 \%)$ and, except for one isolate from Crete, only $25 \%$ of nucleotide changes resulted in amino acid changes (Table 4).

\section{DISCUSSION}

Our data show that CYSDV and BPYV occurred in the Middle East and Mediterranean Europe, but LIYV was not detected in any of our samples. Interestingly, our data also showed that the geographic ranges of CYSDV and BPYV did not overlap; CYSDV was common in Spain and the Middle East, while BPYV was found only in Crete and Italy. LIYV, CYSDV, and BPYV were not recovered from any of the samples from California analyzed here. LIYV is now reported to be very rare in California in several of its host plants (20) and, so far, CYSDV has not been found. However, California data most likely do not reflect the overall incidence of BPYV. Its natural vector, the greenhouse whitefly, $T$. vaporariorum, is not common in open fields and all samples from California were of field-grown cucurbits. T. vaporariorum is common in greenhouses, but commercial cucurbits are not commonly produced in greenhouses in California. In contrast, samples from the Middle East and Mediterranean Europe were from both commercial fields and greenhouses, and the CYSDV vectors, $B$. argentifolii and $B$. tabaci are found in both environments. The nonoverlapping geographic distribution of BPYV and CYSDV seen here for samples from Europe is intriguing. In Spain, displacement of BPYV by CYSDV has been correlated with the increasing establishment

TABLE 3. Number of nucleotide ${ }^{a}$ (upper semimatrix) and amino acid (lower semimatrix) differences of a 465-bp fragment of seven cucurbit yellow stunting disorder virus isolates

\begin{tabular}{|c|c|c|c|c|c|c|c|}
\hline & \multicolumn{3}{|c|}{ Pattern $1^{\text {b }}$} & \multicolumn{2}{|c|}{ Pattern 3} & \multicolumn{2}{|c|}{ Pattern 2} \\
\hline & $\mathrm{S} 1^{\mathrm{c}}$ & $\mathrm{S} 2$ & $\mathrm{~J} 1$ & $\mathrm{~T} 1$ & $\mathrm{~T} 2$ & A1 & $\mathrm{J} 2$ \\
\hline $\mathrm{S} 1$ & $\ldots$ & 1 & 2 & 2 & 3 & 41 & 41 \\
\hline $\mathrm{S} 2$ & 0 & $\ldots$ & 1 & 1 & 2 & 42 & 42 \\
\hline $\mathrm{J} 1$ & 1 & & $\ldots$ & 2 & 3 & 43 & 43 \\
\hline $\mathrm{T} 1$ & 0 & 0 & 1 & $\ldots$ & 1 & 41 & 41 \\
\hline $\mathrm{T} 2$ & 0 & 0 & 1 & 0 & $\ldots$ & 42 & 42 \\
\hline A1 & 8 & 8 & 9 & 8 & 8 & $\ldots$ & 0 \\
\hline $\mathrm{J} 2$ & 8 & 8 & 9 & 8 & 8 & 0 & $\ldots$ \\
\hline
\end{tabular}

a Nucleotide sequences of the primers were not included in this analysis. Only 425 nucleotides were analyzed.

b Single-strand conformation polymorphism patterns correspond to those shown in Figure 1.

${ }^{c}$ Letters indicate geographic origin: $\mathrm{A}=$ Saudi Arabia, $\mathrm{J}=$ Jordan, $\mathrm{S}=$ Spain, and $\mathrm{T}=$ Turkey. Numbers are used to indicate different isolates from the same country.

TABLE 4. Number of nucleotide ${ }^{a}$ (upper semimatrix) and amino acid (lower semimatrix) differences of a 450-bp fragment of five beet pseudo-yellows virus isolates

\begin{tabular}{|c|c|c|c|c|c|}
\hline & \multicolumn{4}{|c|}{ Pattern $\mathrm{B}^{\mathrm{b}}$} & \multirow{2}{*}{$\frac{\text { Pattern A }}{\mathrm{Cr} 1}$} \\
\hline & $\mathrm{Ca} 1^{\mathrm{c}}$ & $\mathrm{Cr} 2$ & I1 & I2 & \\
\hline $\mathrm{Ca} 1$ & $\ldots$ & 3 & 2 & 3 & 6 \\
\hline $\mathrm{Cr} 2$ & 1 & $\ldots$ & 1 & 2 & 3 \\
\hline I1 & 0 & 1 & $\ldots$ & 1 & 4 \\
\hline $\mathrm{I} 2$ & 0 & 1 & 0 & $\ldots$ & 5 \\
\hline $\mathrm{Cr} 1$ & 3 & 2 & 3 & 3 & $\ldots$ \\
\hline
\end{tabular}

a Nucleotide sequences of the primers were not included in this analysis. Only 404 nucleotides were analyzed.

b Single-strand conformation polymorphism patterns correspond to those shown in Figure 1

${ }^{\mathrm{c}}$ Letters indicate geographic origin: $\mathrm{Ca}=$ California (United States), $\mathrm{Cr}=$ Crete, and I = Italy. Numbers are used to indicate different isolates from the same country. 
of B. tabaci and B. argentifolii with respect to T. vaporariorum (3, 4). Similarly, the disappearance of LIYV in southern California has been associated with the displacement of $B$. tabaci by $B$. argentifolii (a very poor vector of LIYV) $(2,10,20)$.

In this work, we have also made a first evaluation of the molecular variation within and between virus isolates for part of the CYSDV and BPYV HSP70 homolog gene. Because direct nucleotide sequence analysis on such a large number of samples was not practical, we used SSCP to initially differentiate between sequence variants. We were able to detect sequence variations lower than $0.5 \%$, similar to the resolution obtained in other SSCP analyses (25). Although SSCP does not provide quantitative data in regard to the genetic distance between sequence variants, the combination of SSCP and nucleotide sequence analysis seems to be an ideal approach to study sequence variation in virus populations.

Our results revealed that each CYSDV and BPYV isolate was composed of a population of closely related sequence variants, yet each isolate had one predominant variant. This population structure is predicted for RNA viruses and is mainly attributed to the combined effects of the high replication error frequency of the RNA polymerase and of selection pressure (14). The CYSDV isolates were distributed into two diverged groups. Each was genetically homogeneous for the genome region analyzed and was predominantly associated with specific geographic areas. Group I isolates were from Spain, Jordan, and Turkey, and group II included all isolates from Saudi Arabia with some isolates also from Spain and Jordan. Nucleotide sequence comparison with two Spanish CYSDV isolates studied previously (GenBank accessions AJ223619 and U67170) revealed that both of these isolates also belong to group I. Although our samples were collected from several different types of cucurbits and from fields and greenhouses, we found no correlation between host type, the culture conditions, and sequence variant. BPYV showed a very low overall incidence (Table 1) and only a few isolates could be analyzed. SSCP and sequence analysis showed that these isolates formed a homogeneous population located in Italy and Crete, and the reference isolate from California showed a very high identity with these isolates (Table 3 ).

The high genetic uniformity seen here is interesting. It is improbable that the mutation rates for CYSDV and BPYV are lower than those for other RNA viruses (8), as different sequence variants were detected for individual isolates. The genetic variation could be limited, in part, due to functional constraints (negative selection) on the HSP70 homolog sequences, as suggested by the low number of amino acid substitutions versus nucleotide substitutions. Likewise, the low global synonymous nucleotide variation between geographically distant isolates might indicate a recent divergence and, therefore, a rapid expansion of these viruses. We also cannot discount that other factors such as constraints in the RNA secondary structure and expression recognition signals (23) could also limit the number of synonymous nucleotide substitutions. Furthermore, although our primers were chosen based on previous analyses $(4,27)$, it is possible that the primers used here could favor the amplification of specific sequences and, thus, underestimate the variability of these viruses.

Such low diversity found in the HSP70 homolog gene of geographically distant BPYV and CYSDV isolates contrasts with the great genetic diversity observed in different genome regions of another member of the family Closteroviridae, citrus tristeza virus (CTV) $(17,19,21,25)$. Comparison of the HSP70 homolog gene sequence of four CTV isolates showed identities ranging from 87 to 93\%, except for one pair with 99.4\% (GenBank accessions U16304, U56902, AF001623, and Y18420). Interestingly, many CTV isolates have been described and some differ widely in their aphid transmissibility and symptoms caused in various host cultivars (22), whereas no biologically distinct isolates were observed in this work or have been previously reported for either BPYV or CYSDV.

So far, only HSP70 homolog gene sequences of BPYV and CYSDV are available (4,6,27) (GenBank accession AJ223619). As more genome sequences are determined, it will be interesting to see if the genetic homogeneity found in the HSP70 homolog sequences is also observed in other genome regions of these viruses.

\section{ACKNOWLEDGMENTS}

L. Rubio was supported by a postdoctoral fellowship from Ministerio de Educacion y Ciencia, Spain. This research was supported, in part, by a grant from Seminis Vegetable Seeds and the University of California. We thank T. Tian, P. Kong, and T. Erickson for helpful discussions and suggestions on the manuscript. We thank L. Yang for excellent assistance.

\section{LITERATURE CITED}

1. Beidler, L. L., Hilliard, P. R., and Rill, R. L. 1982. Ultrasensitive staining of nucleic acids with silver. Anal. Biochem. 126:374-380.

2. Bellows, T. S., Perring, T. M., Gill, R. J., and Headrick, D. H. 1994. Description of a species of Bemisia [Homoptera, Aleyrodidae]. Ann. Entomol. Soc. Am. 87:195-206.

3. Berdiales, B., Bernal, J. J., Saez, E., Woudt, B., and Rodríguez-Cerezo, E. 1999. Occurrence of cucurbit yellow stunting disorder virus (CYSDV) and beet pseudo-yellows virus in cucurbit crops in Spain and transmission of CYSDV by two biotypes of Bemisia tabaci. Eur. J. Plant Pathol. 105:211-215.

4. Célix, A., López-Sesé, A., Almarza, N., Gómez-Guillamón, M. L., and Rodríguez-Cerezo, E. 1996. Characterization of cucurbit yellow stunting disorder virus, a Bemisia tabaci-transmitted closterovirus. Phytopathology 86:1370-1376.

5. Coffin, R. S., and Coutts, R. H. A. 1995. Relationships among Trialeurodes vaporariorum-transmitted yellowing viruses for Europe and North America. J. Phytopathol. (Phytopathol. Z.) 14:375-380.

6. Coutts, R. H. A., and Coffin, R. S. 1996. Beet pseudo-yellows virus is an authentic closterovirus. Virus Genes 13:179-181.

7. Devereux, J., Haeberli, P., and Smithies, O. 1984. A comprehensive set of sequence analysis programs for the VAX. Nucleic Acids Res. 12:387-395.

8. Domingo, E., and Holland, J. J. 1994. Mutation rates and rapid evolution of RNA viruses. Pages 161-184 in: The Evolutionary Biology of Viruses S. S. Morse, ed. Raven Press, New York.

9. Duffus, J. E. 1965. Beet pseudo-yellows virus, transmitted by the greenhouse whitefly (Trialeurodes vaporariorum). Phytopathology 55:450-453.

10. Duffus, J. E., Larsen, R. C., and Liu, H. Y. 1986. Lettuce infectious yellows virus-A new type of whitefly-transmitted virus. Phytopathology 76:97-100.

11. Falk, B. W., and Klaassen, V. 1995. Lettuce infectious yellows virus: A bipartite closterovirus transmitted by Bemisia, and representative of a new genus of plant viruses. Pages 265-275 in: BEMISIA: Taxonomy, Biology, Damage, Control and Management. D. Gerling and R. T. Mayer, eds. Intercept Press, Andover, United Kingdom.

12. Falk, B. W., Klaassen, V. A., and Tsai, J. H. 1989. Complementary DNA cloning and hybridization analyses of maize stripe virus RNAs. Virology 173:338-342.

13. Hayashi, K. 1991. PCR-SSCP: A simple and sensitive method for detection of mutations in the genomic DNA. PCR Methods Appl. 1:34-38.

14. Holland, J. J., Spindler, K., Horodyski, F., Grabau, E., Nichol, S., and VandePol, S. 1982. Rapid evolution of RNA genomes. Science 215: 1577-1582.

15. Klaassen, V. A., Boeshore, M., Dolja, V. V., and Falk, B. W. 1994. Partial characterization of the lettuce infectious yellows virus genomic RNAs, identification of the coat protein gene and comparison of its amino acid sequence with those of other filamentous RNA plant viruses. J. Gen. Virol. 75:1525-1533.

16. Klaassen, V. A., Boeshore, M., Koonin, E. V., Tian, T. Y., and Falk, B. W. 1995. Genome structure and phylogenetic analysis of lettuce infectious yellows virus, a whitefly-transmitted, bipartite closterovirus. Virology 208:99-110.

17. López, C., Ayllón, M. A., Navas-Castillo, J., Guerri, J., Moreno, P., and Flores, R. 1998. Molecular variability of 5'- and $3^{\prime}$-terminal regions of citrus tristeza virus RNA. Phytopathology 88:685-691.

18. Martelli, G. P., Agranovsky, A. A., Bar-Joseph, M., Boscia, D., Candresse, T., Coutts, R. H. A., Dolja, V. V., Duffus, J. E., Falk, B. W., Gonsalves, D., Jelkmann, W., Karasev, A. V., Minafra, A., Murant, A., Namba, S., Niblett, C. L., Vetten, H. J., and Yoshikawa, N. Family Closteroviridae. In: Rep. Int. Comm. Taxonomy Viruses, 7th. M. H. V. van Regenmortel, C. M. Fauquet, and D. H. L. Bishop, eds. Academic Press, San Diego, CA. In press.

19. Mawassi, M., Gafny, R., and Bar-Joseph, M. 1993. Nucleotide sequence of the coat protein gene of citrus tristeza virus: Comparison of biologically diverse isolates collected in Israel. Virus Genes 7:265-275. 
20. McLain, J., Castle, S., Holmes, G., and Creamer, R. 1998. Physiochemical characterization and field assessment of lettuce chlorosis virus. Plant Dis. 82:1248-1252.

21. Pappu, H. R., Pappu, S., Niblett, C. L., Lee, R. F., and Civerolo, E. L. 1993. Comparative sequence analysis of the coat protein of biologically distinct citrus tristeza closterovirus isolates. Virus Genes 7:255-264.

22. Roistacher, C. N., and Moreno, P. 1991. The worldwide threat from destructive isolates of citrus tristeza virus-A review. Pages 7-19 in: Proc. Conf. Int. Org. Citrus Virol., 11th. R. M. Brlansky, R. F. Lee, and L. W. Timmer, eds. IOCV, Riverside, CA.

23. Roossinck, M. J. 1997. Mechanism of plant virus evolution. Annu. Rev. Phytopathol. 356:191-209.

24. Rubio, L. 1997. Diferenciacion y caracterizacion molecular de aislados del virus de la tristeza de los citricos (CTV). Aplicacion al control de la enfermedad. Ph.D. thesis. Universitat de Valencia, Facultad de Ciencias
Biologicas, Valencia, Spain

25. Rubio, L., Ayllon, M. A., Guerri, J., Pappu, H., Niblett, C., and Moreno, P. 1996. Differentiation of citrus tristeza closterovirus (CTV) isolates by single-strand conformation polymorphism analysis of the coat protein gene. Ann. Appl. Biol. 129:479-489.

26. Sambrook, J., Fritsch, E. F., and Maniatis, T. 1989. Molecular Cloning: A Laboratory Manual. Cold Spring Harbor Laboratory, Cold Spring Harbor, NY.

27. Tian, T., Klaassen, V. A., Soong, J., Wisler, G., Duffus, J. E., and Falk, B. W. 1996. Generation of cDNAs specific to lettuce infectious yellows closterovirus and other whitefly-transmitted viruses by RT-PCR and degenerate oligonucleotide primers corresponding to the closterovirus gene encoding the heat shock protein 70 homolog. Phytopathology 86:11671173.

28. Wisler, G. C., Duffus, J. E., Liu, H.-Y., and Li, R. H. 1998. Ecology and epidemiology of whitefly-transmitted closteroviruses. Plant Dis. 82:270-280. 